\title{
The effects of vitamin D on severity of coronary artery atherosclerosis and lipid profile of cardiac patients
}

Ewelina A. Dziedzic ${ }^{1,2}$, Sebastian Przychodzeń ${ }^{1,2}$, Marek Dąbrowski ${ }^{1,2}$

${ }^{1}$ Cardiology Clinic of Physiotherapy Division, $2^{\text {nd }}$ Faculty of Medicine, Medical University of Warsaw, Warsaw, Poland

2Department of Cardiology, Bielański Hospital, Warsaw, Poland

Submitted: 16 September 2015

Accepted: 28 October 2015

Arch Med Sci 2016; 12, 6: 1199-1206

DOI: 10.5114 /aoms.2016.60640

Copyright $\odot 2016$ Termedia \& Banach

\section{Abstract}

Introduction: A deficiency of 25-hydroxyvitamin D (25(OH)D) (the standard biomarker for vitamin D status) can have multiple impacts on the cardiovascular system. The aim of the study was to assess of the influence of $25(\mathrm{OH}) \mathrm{D}$ on severity of coronary atherosclerosis and lipid profile.

Material and methods: The study involved prospectively 637 patients subject to coronary catheterization. The stage of coronary atherosclerosis was assessed using the Coronary Artery Surgery Study score (CASSS). Plasma concentration of 25(OH)D was measured using an electrochemiluminescent immunoassay. The levels of total cholesterol (TC), high-density cholesterol (HDL-C) and triglycerides (TG) were measured using the enzymatic method, and the concentration of low-density cholesterol (LDL-C) was calculated with the Friedewald equation.

Results: The average level of 25(OH)D was $15.85 \mathrm{ng} / \mathrm{ml}$. A higher level of $25(\mathrm{OH}) \mathrm{D}$ was observed in men $(16.28 \mathrm{ng} / \mathrm{ml}$ vs. $15.1 \mathrm{ng} / \mathrm{ml} ; p=0.027)$. The study did not reveal any significant correlation between the level of $25(\mathrm{OH}) \mathrm{D}$ and severity of coronary atherosclerosis. It was observed however that the increase of 25(OH)D level results in an increased number of patients without significant lesions in the coronary arteries. In the whole group of women and men in the age group of 70-80 years an inverse relationship was observed between the level of $25(\mathrm{OH})$ and the severity of coronary atherosclerosis. The whole study group showed a statistically significant inverse correlation of the 25(OH)D level with TC $(p=0.0057)$, LDL-C $(p=0.00037)$ and TG $(p=0.00017)$.

Conclusions: Women and men over 70 years showed an inverse correlation of the $25(\mathrm{OH}) \mathrm{D}$ level and the stage of coronary atherosclerosis. Deficiency of 25(OH)D affects the levels of TC, LDL-C and TG.

Key words: vitamin D, coronary atherosclerosis, gender, lipid profile.

\section{Introduction}

Coronary atherosclerosis is the main cause of death in developed countries. In spite of important progress in medication and improvement in techniques of coronary intervention, the therapeutic outcome is still not satisfactory. So far, several risk factors of a cardiovascular event have been identified; however, much attention is still paid to finding new ones. Some people propose vitamin D deficiency, affecting $50 \%$ of the world population, which may increase occurrence of cardiovascular diseases [1-3].

\author{
Corresponding author: \\ Prof. Marek Dąbrowski MD, \\ $\mathrm{PhD}$ \\ Department of Cardiology \\ $2^{\text {nd }}$ Faculty of Medicine \\ Medical University of Warsaw \\ Bielanski Hospital \\ 80 Cegłowska St \\ 01-809 Warsaw, Poland \\ Phone/fax: +48 225690292 \\ E-mail: marekda@bielanski. \\ med.pl
}


The main source of vitamin D in the body (80$90 \%$ ) is dermal synthesis, whereby ultraviolet radiation of 7-dehydrocholesterol is converted into pro-vitamin $D_{3}$, which is rapidly converted in the liver to form the main circulating 25-hydroxyvitamin D (25(OH)D). 25(OH)D status reflects the resources of vitamin $D$ in the body.

Moreover, recent test results showed an independent relation between low levels of vitamin $D$ and documented risk factors of cardiovascular event such as hypertension [4], atherogenic lipid profile [5], diabetes [6], and obesity [7]. Particularly noteworthy is the effect of vitamin D on the lipid profile. An association of high levels of total cholesterol and low-density cholesterol (LDL-C) with coronary atherosclerosis is expressly documented. It was also found that the reduction of total cholesterol and low-density lipoprotein below the recommended level significantly decreases the cardiovascular risk [8,9]. Many studies have found an inverse relationship of 25(OH)D in serum and different cholesterol fractions [10].

Inflammation found in the wall of large and medium arteries in the course of atherosclerosis is induced in response to destruction of endothelium [11]. It was demonstrated that calcitriol is able to normalize endothelial cell function through decreased production of reactive oxygen species [12], increased activity of endothelial nitric oxide synthase [12, 13], and protection of endothelial cells from end-products of glycosylation [14]. Furthermore, it regulates proliferation, differentiation and function of immune system cells through inhibition of prostaglandin and cyclooxygenase-2 synthesis and induction of anti-inflammatory cytokines [15-18]. The influence of calcitriol on calcification of the vascular wall is unclear. In low concentrations calcitriol inhibits calcification of the tunica media and interna in coronary arteries $[19,20]$. On the other hand, in high concentrations it stimulates differentiation of mesenchymal cells into osteoblasts [21].

A thin layer of connective tissue, large lipid nucleus, activity of inflammatory cells and increased neovascularisation are the main factors involved in destabilization of the atherosclerotic plaque [11]. Apart from its anti-inflammatory properties, calcitriol inhibits transformation of macrophages into foam cells [22], inhibits the activity of metalloproteinases [23, 24], and negatively influences angiogenesis by inhibition of vascular endothelial growth factor (VEGF) and induction of apoptosis in epithelial cells [25].

After rupture of the atherosclerotic plaque, its lipid contents are released and the blood coagulation process is initiated [11]. Calcitriol exerts its anticoagulant activity through down-regulation of tissue factor, increased production of thrombo- modulin [26] and inhibition of platelet adhesion to endothelium [27].

The aim of our study is to assess the influence of vitamin $D$ level on the condition of coronary arteries and lipid profile of patients subject to cardiac catheterization. The obtained results can contribute to enhancement of the strategy in prevention of coronary heart disease.

\section{Material and methods}

\section{Population}

The study comprised 637 patients (415 men and 222 women) of Bielański Hospital, Cardiology Department, aged $64 \pm 9.7$ (from 31 to 87 years old) who underwent cardiac catheterization between July 2013 and May 2015.

The study patients were selected on the basis of ambulatory diagnostics for coronary angiography for suspected coronary artery disease, and upon meeting the study's criteria.

The study excluded patients with chronic kidney disease (stages $I I I-V$ ) due to accompanying disorders of calcium and phosphate. Although the pathogenesis of these abnormalities is multifactorial, abnormal parathyroid hormone (PTH) secretion and vitamin $\mathrm{D}$ metabolism respectively seem to play a leading role in their development [28]. In addition, the study excluded patients with cancer (paraneoplastic syndromes and associated disorders of calcium-phosphate), patients with elevated markers of inflammation or fever, and those taking drugs or dietary supplements containing vitamin D or calcium. Those included in the study formed a homogeneous group in terms of diet and eating habits and length of exposure to sunlight. All the patients were treated with a statin (atorvastatin or rosuvastatin).

All the patients gave their agreement in writing to participate in the study. The test protocol was accepted by the Bioethics Committee of the Medical University of Warsaw.

\section{Methods}

All the patients were subject to cardiac catheterization using standard diagnostic catheters (access by radial or femoral artery). The severity of coronary atherosclerosis was assessed using the CASSS. Each of the three important epicardial vessels of stenosis $>70 \%$ was assigned one point. Left main coronary artery stenosis $\geq 50 \%$ was classified as 2-vessel coronary artery disease and was assigned two points. CASSS is a sum of all points reflecting one-, two-, and three-vessel coronary artery disease.

Plasma concentration of $25(\mathrm{OH}) \mathrm{D}$ was measured using the Vitamin D Total assay (ELECSYS Roche Diagnostics). This is a competitive electro- 
chemiluminescence assay using a phenomenon where the identification of $25(\mathrm{OH}) \mathrm{D}_{2}$ and $25(\mathrm{OH}) \mathrm{D}_{3}$ used vitamin D binding protein (DBP) labeled with ruthenium. More accurate methods (using high-performance liquid chromatography or mass spectrometry) allowing for separate determination of $25(\mathrm{OH}) \mathrm{D}_{3}$ and $25(\mathrm{OH}) \mathrm{D}_{2}$ are expensive and used less often. It is believed that globally designated $25(\mathrm{OH}) \mathrm{D}_{3}+25(\mathrm{OH}) \mathrm{D}_{2}$ is reasonable, given that the biological effects of these two metabolites are similar.

The 25(OH)D limit of detection was $4 \mathrm{ng} / \mathrm{ml}$. It was considered that the optimal level of $25(\mathrm{OH}) \mathrm{D}$ is over $30 \mathrm{ng} / \mathrm{ml}$, a slight deficiency is between 20 and $30 \mathrm{ng} / \mathrm{ml}$, a moderate deficiency is between 10 and $20 \mathrm{ng} / \mathrm{ml}$, and hypovitaminosis $D_{3}$ is under $10 \mathrm{ng} / \mathrm{ml}$.

The levels of total cholesterol (TC), high-density cholesterol (HDL-C) and triglycerides (TG) were measured using the enzymatic method, and the concentration of LDL-C was calculated using the Friedewald equation.

Body mass index (BMI) was calculated to determine the degree of obesity (BMI > $30 \mathrm{~kg} / \mathrm{m}^{2}$ ). The BMI was calculated by dividing the subject's mass by the square of his or her height, expressed in metric units.

\section{Statistical analysis}

The arithmetic mean and standard deviation were calculated for quantitative variables. The quantitative and percentage distributions were presented for qualitative variables. Pearson's $\chi^{2}$ test was applied to check variable interdependence. Parametric tests (Student's t-test, Welch's test) and the non-parametric Wilcoxon signedrank test were applied to compare two independent tests with quantitative variables. Values of $p<0.05$ were considered as statistically significant.

\section{Results}

Men made up $65 \%$ of the patients. Hypertension was observed in $90.1 \%$; diabetes in $29.2 \%$;

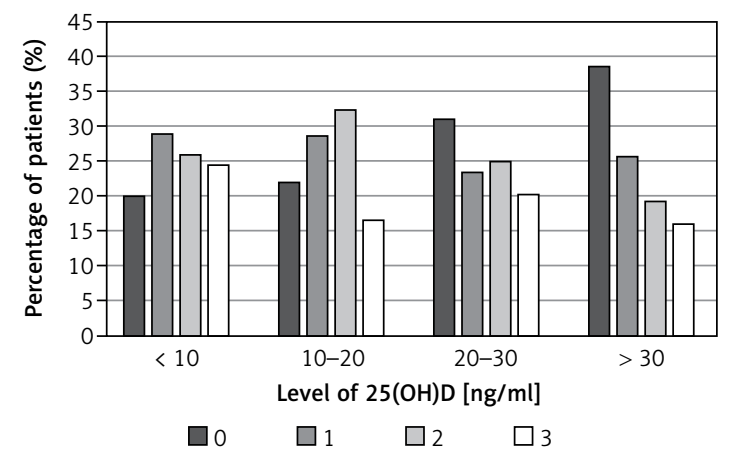

Figure 1. Correlation between the level of $25(\mathrm{OH}) \mathrm{D}$ and severity of coronary atherosclerosis (CASSS score) prediabetes in 6\%, hyperlipidemia in $49.6 \% .26 .3 \%$ of the population were active tobacco smokers, whereas $16.7 \%$ of the patients mentioned smoking in the interview. Stable coronary disease was the cause of hospitalization in $67.1 \%$, acute coronary syndrome in $32.9 \%$. $26.6 \%$ of the patients mentioned heart failure in the past. The average BMI was $28.49 \mathrm{~kg} / \mathrm{m}^{2}\left(28.8 \mathrm{~kg} / \mathrm{m}^{2}\right.$ in women, $29.1 \mathrm{~kg} / \mathrm{m}^{2}$ in men).

No significant lesions in coronary arteries were observed in $24.3 \%$ of the patients, single-vessel disease in $27.6 \%$, two-vessel disease in $29 \%$, and three-vessel disease in $19 \%$ of the patients.

The average level of 25(OH)D was $15.85 \mathrm{ng} / \mathrm{ml}$ (from 4.0 to $48.4 \mathrm{ng} / \mathrm{ml}$ ). The optimal level was observed in just $4.9 \%$ of the patients. Severe deficiency was observed in $21 \%$ of the patients, moderate deficiency in 54\%, and slight deficiency in $20 \%$.

No statistically significant correlation between the level of 25(OH)D and the severity of coronary atherosclerosis $(p=0.088)$ was observed for the whole population. One should bear in mind, however, that the result is close to significance, and the percentage of patients with no significant lesions in coronary arteries increases with the increase of 25(OH)D level; Figure 1.

A statistically significant correlation between the level of 25(OH)D and gender $(p=0.0033)$ was observed. The average levels of 25(OH)D for women $(15.1 \mathrm{ng} / \mathrm{ml})$ were statistically significantly lower than the average levels of 25(OH)D for men (16.27 ng/ml); Figure 2.

Moreover, a significantly lower level of 25(OH)D was observed in women suffering from advanced coronary artery disease (two- and three-vessel). The average level of $25(\mathrm{OH}) \mathrm{D}$ in women with no significant lesions in the coronary arteries was $17.5 \pm 9 \mathrm{ng} / \mathrm{ml}$, in the group of two- and three-vessels disease $13.4 \pm 6.1 \mathrm{ng} / \mathrm{ml} ; p=0.0008$; Figure 3 .

Men aged $70-80$ years were also found to have a significantly lower level of $25(\mathrm{OH}) \mathrm{D}$ for patients suffering from two- and three-vessel coronary atherosclerosis in comparison to patients without significant lesions in coronary arteries $(16.3 \pm 7.8 \mathrm{ng} / \mathrm{ml}$

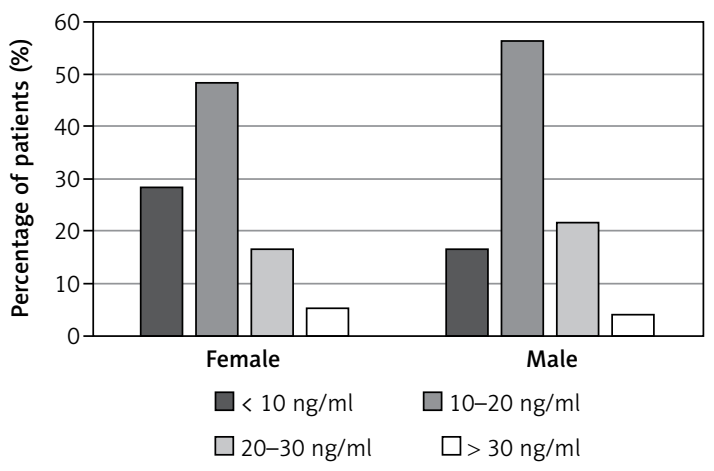

Figure 2. Correlation between the level of $25(\mathrm{OH}) \mathrm{D}$ and gender 


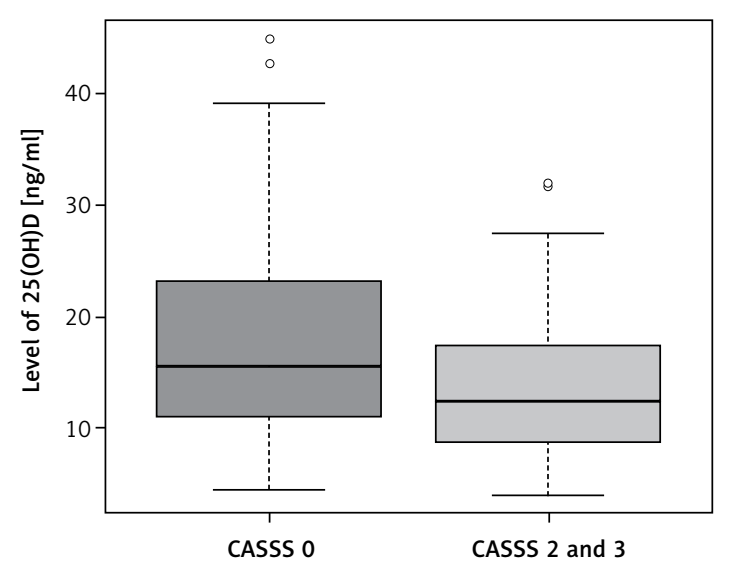

Figure 3. Correlation between the level of $25(\mathrm{OH}) \mathrm{D}$ in women without coronary atherosclerosis and with advanced coronary atherosclerosis

vs. $19.1 \pm 5.9 \mathrm{ng} / \mathrm{ml} ; p=0.026$ ); Figure 4 . This correlation could not be confirmed for the whole group of men.

There was no significant correlation between the level of $25(\mathrm{OH}) \mathrm{D}$ and patients' $\mathrm{BMI}(p=0.7)$, hypertension ( $p=0.7$ ) or diabetes $(p=0.87)$.

However, an inverse correlation between $25(\mathrm{OH}) \mathrm{D}$ concentration and the concentrations of TC $(p=0.0057)$, LDL-C $(p=0.00037)$, and TG ( $p=0.00017)$ was found, Table I. The average levels of TC, LDL-C and TG were statistically sig-

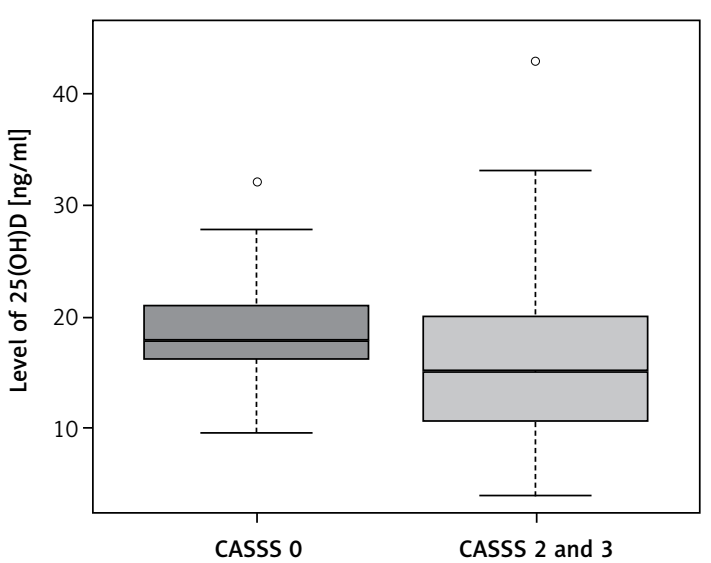

Figure 4. Correlation between the level of $25(\mathrm{OH}) \mathrm{D}$ and severity of coronary atherosclerosis in men aged $70-80$ years

nificantly lower in patients with the optimal level of $25(\mathrm{OH}) \mathrm{D}$ in comparison to patients suffering from severe vitamin $D$ deficiency. The analysis of the results taking into consideration gender showed a statistically significant inverse correlation between 25(OH)D and TC ( $p=0.047)$, LDL-C $(p=0.0036)$ and TG $(p=0.006)$ in women. In men, the only statistically significant correlation was found in relation to $25(\mathrm{OH}) \mathrm{D}$ and $\mathrm{TG}(p=0.029)$. It should be stressed that for LDL-C, the correlation was close to statistical significance $(p=0.052)$. No

Table I. Correlation between the level of 25(OH)D and TC, LDL-C and TG

\begin{tabular}{|c|c|c|c|c|c|c|c|c|c|}
\hline $\begin{array}{l}\text { Level of } \\
25(\mathrm{OH}) \mathrm{D} \\
{[\mathrm{ng} / \mathrm{ml}]}\end{array}$ & $\begin{array}{c}\text { TC } \\
\text { average } \\
\text { [mg/dl] }\end{array}$ & SD & IQR & Min. & $\begin{array}{c}\text { First } \\
\text { quartile }\end{array}$ & Median & $\begin{array}{c}\text { Third } \\
\text { quartile }\end{array}$ & Max. & $\begin{array}{c}\text { Number } \\
\text { of } \\
\text { patients }\end{array}$ \\
\hline$<10$ & 189.11 & 54.09 & 78.82 & 63.1 & 149.38 & 178.9 & 228.2 & 366.29 & 125 \\
\hline $10-20$ & 178.74 & 44.79 & 58.375 & 70.29 & 146.955 & 172 & 205.33 & 334.08 & 315 \\
\hline $20-30$ & 180.63 & 99.88 & 61.29 & 73.25 & 140.055 & 167.59 & 201.34 & 264.36 & 115 \\
\hline$>30$ & 157.23 & 43.03 & 51.8725 & 70.02 & 132.40 & 147.5 & 184.27 & 237.9 & 30 \\
\hline $\begin{array}{l}\text { Level of } \\
25(\mathrm{OH}) \mathrm{D} \\
{[\mathrm{ng} / \mathrm{ml}]}\end{array}$ & $\begin{array}{c}\text { LDL-C } \\
\text { average } \\
\text { [mg/dl] }\end{array}$ & SD & $\mathrm{IQR}$ & Min. & $\begin{array}{c}\text { First } \\
\text { quartile }\end{array}$ & Median & $\begin{array}{c}\text { Third } \\
\text { quartile }\end{array}$ & Max. & $\begin{array}{c}\text { Number } \\
\text { of } \\
\text { patients }\end{array}$ \\
\hline$<10$ & 114.27 & 46.16 & 65.39 & 24.43 & 82.86 & 109.03 & 148.25 & 253.02 & 125 \\
\hline $10-20$ & 104.03 & 40.12 & 49.56 & 23.48 & 76.45 & 98.35 & 126.01 & 257.97 & 311 \\
\hline $20-30$ & 97.04 & 40.79 & 54.79 & 22.29 & 68.84 & 88.23 & 123.63 & 202.12 & 113 \\
\hline$>30$ & 83.03 & 33.44 & 36.72 & 31.79 & 60.65 & 77.19 & 97.37 & 153.86 & 30 \\
\hline $\begin{array}{l}\text { Level of } \\
25(\mathrm{OH}) \mathrm{D} \\
{[\mathrm{ng} / \mathrm{ml}]}\end{array}$ & $\begin{array}{c}\text { TG } \\
\text { average } \\
\text { [mg/dl] }\end{array}$ & SD & $\mathrm{IQR}$ & Min. & $\begin{array}{c}\text { First } \\
\text { quartile }\end{array}$ & Median & $\begin{array}{c}\text { Third } \\
\text { quartile }\end{array}$ & Max. & $\begin{array}{c}\text { Number } \\
\text { of } \\
\text { patients }\end{array}$ \\
\hline$<10$ & 139.06 & 64.66 & 76.92 & 46.94 & 89.80 & 133.595 & 166.73 & 386.39 & 124 \\
\hline 10-20 & 129.39 & 65.61 & 68.34 & 2.81 & 87.71 & 114.91 & 156.04 & 456.7 & 316 \\
\hline $20-30$ & 123.91 & 61.58 & 59.59 & 37.07 & 58.52 & 111.82 & 145.11 & 438.25 & 115 \\
\hline$>30$ & 96.14 & 52.36 & 35.77 & 43.3 & 69.07 & 86.325 & 104.83 & 331.57 & 30 \\
\hline
\end{tabular}

$S D$ - standard deviation, IQR - interquartile range, Min. - minimum value, Max. - maximum value. 
Table II. Characteristics of the examined group

\begin{tabular}{|c|c|c|c|c|}
\hline Laboratory variables & Avarge & SD & Min. & Max. \\
\hline $25(\mathrm{OH}) \mathrm{D}[\mathrm{ng} / \mathrm{ml}]$ & 15.85 & 7.34 & 4 & 48.4 \\
\hline BMI & 28.49 & 5.06 & 16.14 & 54.06 \\
\hline Age at the time of the study & 66 & 10.38 & 31 & 95 \\
\hline PTH [pg/ml] & 50.88 & 27.33 & 13.2 & 219 \\
\hline Calcium in serum $[\mathrm{mmol} / \mathrm{l}]$ & 2.35 & 0.14 & 1.01 & 3.04 \\
\hline Phospathes in serum $[\mathrm{mmol} / \mathrm{l}]$ & 1.11 & 0.2 & 0.58 & 2.58 \\
\hline $\mathrm{TC}[\mathrm{mg} / \mathrm{dl}]$ & 178.77 & 46.99 & 70.02 & 366.29 \\
\hline $\mathrm{HDL}[\mathrm{mg} / \mathrm{dl}]$ & 48.68 & 14.78 & 8.85 & 113.24 \\
\hline $\mathrm{LDL}[\mathrm{mg} / \mathrm{dl}]$ & 104.08 & 41.8 & 22.29 & 257.97 \\
\hline TG [mg/dl] & 129.55 & 64.55 & 31.3 & 456.7 \\
\hline Uric acid [mg/dl] & 6.2 & 1.76 & 2.58 & 14 \\
\hline Data from the medical history & \multicolumn{4}{|c|}{ Number of patients } \\
\hline Diagnosis of unstable angina & \multicolumn{4}{|c|}{209} \\
\hline Diagnosis of stable angina & \multicolumn{4}{|c|}{428} \\
\hline Interview myocardial infarction & \multicolumn{4}{|c|}{169} \\
\hline History of prior CABG & \multicolumn{4}{|c|}{24} \\
\hline Patients with diabetes/pre-diabetes & \multicolumn{4}{|c|}{$185 / 38$} \\
\hline Active smokers or smokers in the past & \multicolumn{4}{|c|}{$167 / 106$} \\
\hline
\end{tabular}

SD - standard deviation, Min. - minimum value, Max. - maximum value.

correlation of 25(OH)D and HDL-C was found for the whole population. Characteristics of the study group of patients was presented in Table II.

\section{Discussion}

There is more and more evidence that vitamin D deficiency significantly increases the risk of a cardiovascular event, and the optimal vitamin D concentration shows protective properties [29, 30]. To our knowledge this is the first study carried out on Polish patients to assess the influence of vitamin $D$ on the severity of coronary atherosclerosis.

Vitamin D deficiency was found in $95.1 \%$ of the patients. This confirms a former analysis which found a high frequency of vitamin D deficiency in Poland [31].

In spite of the fact that there was no significant correlation between the level of $25(\mathrm{OH}) \mathrm{D}$ and the severity of coronary atherosclerosis, it should be stressed that $38.7 \%$ of the patients with the optimal level of $25(\mathrm{OH}) \mathrm{D}$ had no significant lesions in the coronary arteries, and $16.1 \%$ suffered from three-vessel coronary artery disease. The percentage of patients with no significant lesions in coronary arteries increases along with the level of vitamin D. The analysis of former studies provides various results for the effect of 25(OH)D deficiency on the condition of coronary arteries. Verdoia et al. carried out a study on 1484 patients subject to cardiac catheterization that showed a significant correlation between vitamin D deficiency and severity of coronary artery disease, especially in patients with $25(\mathrm{OH}) \mathrm{D}<10 \mathrm{ng} / \mathrm{ml}$ [32]. The Multi-Ethnic Study of Atherosclerosis, which included 6436 patients with coronary artery disease, showed a higher risk of cardiovascular events in white people with a lower level of 25(OH)D [33]. However, Goleniewska et al. examined a group of 130 patients hospitalized for the first heart attack with ST-segment elevation and did not detect any correlation between the level of vitamin D and the severity of lesions in coronary arteries. However, the study showed a high percentage of vitamin D deficiency in this group of patients [34].

The analysis of our results carried out with division into genders showed a statistically significant inverse correlation between $25(\mathrm{OH}) \mathrm{D}$ and the severity of coronary atherosclerosis in women, who were found to have higher severity of coronary atherosclerosis at a lower level of 25(OH)D. Similarly, Verdoia et al. documented a more advanced stage of coronary atherosclerosis in female patients with a lower level of 25(OH)D [35].

Similar correlations between the level of $25(\mathrm{OH}) \mathrm{D}$ and the severity of coronary artery disease were found in men aged $70-80$ years. 
The difference of vitamin $D$ levels in women and men is interesting and important to highlight. The study revealed significantly lower levels of $25(\mathrm{OH}) \mathrm{D}$ in women, which confirms studies of other researchers [36]. Moreover, taking into consideration the correlation between the level of $25(\mathrm{OH}) \mathrm{D}$ and the severity of coronary atherosclerosis, found in the whole group of women, the special position of vitamin $\mathrm{D}$ is apparent, and we hold the view that further studies need to be carried out to make recommendations in the field of supplementation in this group of patients.

It is especially important to highlight the influence of vitamin $D$ on the lipid profile, given the fact that the correlation between the high levels of total cholesterol and LDL-C and coronary atherosclerosis is explicitly documented. Moreover, it was shown that levels of TC and LDL-C below recommended levels significantly reduce the risk of cardiovascular events [37, 38].

Our study showed inverse correlations between the $25(\mathrm{OH}) \mathrm{D}$ concentration and the concentrations of TC, LDL-C and TG in the whole examined population. The result of analysis carried out according to gender showed statistically significant inverse correlations of the level of $25(\mathrm{OH}) \mathrm{D}$ with TC, LDL-C and TG in the group of examined women. In men, however, a statistically significant correlation of $25(\mathrm{OH}) \mathrm{D}$ was found only with TG, while the correlation with LDL-C was close to statistical significance. No association between 25(OH)D and HDL-C was found both for the whole group and separately for women and men. Similar results were obtained by Garcia-Bailo et al. in a Canadian population [39]. Other researchers also found an inverse correlation between $25(\mathrm{OH}) \mathrm{D}$ and various lipid fractions in the serum [40].

The results described above can be explained by analyzing the metabolic pathway, common for vitamin D and cholesterol. Both these substances are formed from the common precursor of 7-dehydrocholesterol. The key role in the synthesis is played by 3-hydroxy-3-methyl-glutaryl-CoA reductase (HMG-CoA). It was experimentally shown on various cell lines that hydroxylated derivatives of vitamin $D$ are inhibitory to the activity of HMG-CoA reductase [41]. This effect is not observed for the active vitamin $\mathrm{D}$ metabolite 1,25 dihydroxycholecalciferol. Moreover, 25(OH)D can inhibit CYP51A1, which also participates in cholesterol synthesis. Deficiency of $25(\mathrm{OH}) \mathrm{D}$ increases the activity of the reductase and CYP51A1 by increasing the level of cholesterol. Blocking HMG-CoA reductase is the key function of statins. Studies of statins and increase of the $25(\mathrm{OH}) \mathrm{D}$ levels, observed during treatment with some statins, shed some light on the pleiotropic action of this medication [42-44]. It is thought that blocking HMG-CoA reductase, which prevents cholesterol synthesis, promotes the pathway of synthesis of cholecalciferol from 7-dehydrocholesterol. This reaction is responsible for some of the pleiotropic actions of statin, including bone metabolism. The influence of $25(\mathrm{OH}) \mathrm{D}$ on treatment with statins is a separate issue. It was observed that patients with the correct level of $25(\mathrm{OH}) \mathrm{D}$ as well as those with a slight deficiency showed significantly better reduction of the total cholesterol and triglyceride levels during treatment with atorvastatin in comparison to patients showing severe deficiency [45]. The mechanism behind this observation probably concerns the influence of CYP3A4 and requires further study.

Our findings were based on a single population center and would need to be verified in other, larger cohorts. In addition, although patients reported roughly comparable exposure to sunlight, we were not able to exactly determine intake of vitamin D and calcium in the diet. The study did not include the use of solar filters that significantly affect the cutaneous synthesis of vitamin D. In addition, we did not take into account the status of menopause or hormonal levels in women, and it is not possible to exclude the effect of hormones on the condition of the coronary arteries. No polymorphisms were tested for the vitamin D receptor or the level of vitamin $\mathrm{D}$ binding protein.

In conclusion, vitamin D deficiency was observed in $95.1 \%$ of the patients subject to cardiac catheterization. It was found that the level of $25(\mathrm{OH}) \mathrm{D}$ significantly depends on gender. An inverse correlation between the level of $25(\mathrm{OH}) \mathrm{D}$ and severity of coronary atherosclerosis was found in women and men over 70 years old. In the group of women, a statistically significant inverse correlation between 25(OH)D and TC, LDL-C and TG was found. Although the recommendations of scientific societies did not include vitamin D supplementation as a method of prevention of coronary atherosclerosis, we need additional studies to evaluate the potential benefits of vitamin $D$ supplementation in the prevention and progression of coronary artery disease, especially considering the fact that vitamin D supplementation is an inexpensive treatment option compared with the costs of treating the effects of coronary artery disease (acute coronary events, heart failure, etc).

\section{Conflict of interest}

The authors declare no conflict of interest.

\footnotetext{
References

1. Zittermann A, Schleithoff SS, Koerfer R. Putting cardiovascular disease and vitamin $D$ insufficiency into perspective. Br J Nutr 2005; 94: 483-92.

2. Holick MF. Vitamin D deficiency. N Engl J Med 2007; 357: 266-81.
} 
3. Holick MF, Binkley NC, Bischoff-Ferrari HA, et al. Evaluation, treatment, and prevention of vitamin D deficiency: an Endocrine Society clinical practice guideline. J Clin Endocrinol Metab 2011; 96: 1911-30.

4. Ferrario CM, Strawn WB. Role of the renin-angiotensin-aldosterone system and proinflammatory mediators in cardiovascular disease. Am J Cardiol 2006; 98 121-8.

5. Gagnon C, Lu ZX, Magliano DJ, et al. Low serum 25-hydroxyvitamin $D$ is associated with increased risk of the development of the metabolic syndrome at five years: results from a national, population-based prospective study. J Clin Endocrinol Metab 2012; 97: 1953-61.

6. Pittas AG, Lau J, Hu FB, Dawson-Hughes B. The role of vitamin $D$ and calcium in type 2 diabetes. A systematic review and metaanalysis. J Clin Endocrinol Metab 2007; 92: 2017-29.

7. Lamendola CA, Ariel D, Feldman D, Reaven GM. Relations between obesity, insulin resistance, and 25-hydroxyvitamin D. Am J Clin Nutr 2012; 95: 1055-105.

8. Cannon $\mathrm{CP}$, Braunwald E, McCabe $\mathrm{CH}$, et al. Intensive versus moderate lipid lowering with statins after acute coronary syndromes. N Engl J Med 2004; 15: 1495-504.

9. Gupta AK, Sexton RC, Rudney H. Effect of vitamin D3 derivatives on cholesterol synthesis and HMG-CoA reductase activity in cultured cells. J Lipid Res 1989; 30: 379-86.

10. Pittas AG, Lau J, Hu FB, Dawson-Hughes B. The role of vitamin $\mathrm{D}$ and calcium in type 2 diabetes. A systematic review and metaanalysis. J Clin Endocrinol Metab 2007; 92: 2017-29.

11. Beręsewicz A. Pathophysiology of atherosclerosis and cardiovascular disease. Poland 2011; 25-30.

12. Dong J, Wong SL, Lau CW, et al. Calcitriol protects renovascular function in hypertension by down-regulating angiotensin II type 1 receptors and reducing oxidative stress. Eur Heart J 2012; 33: 2980-90.

13. Jablonski KL, Chonchol M, Pierce GI, Walker AE, Seals DR. 25-hydroxyvitamin $D$ deficiency is associated with in flammation-linked vascular endothelial dysfunction in middle-aged and older adults. Hypertension 2011; 57: 63-9.

14. Talmor Y, Golan E, Benchetrit S, et al. Calcitriol blunts the deleterious impact of advanced glycation end products on endothelial cells. Am J Physiol Renal Physiol 2008; 294: 1059-64.

15. Bobryshev YV. Vitamin D3 suppresses immune reactions in atherosclerosis, affecting regulatory $T$ cells and dendritic cell function. Arterioscler Thromb Vasc Biol 2010; 30: 2317-9.

16. Prietl B, Pilz S, Wolf M, et al. Vitamin D supplementation and regulatory $T$ cells in apparently healthy subjects: vitamin $D$ treatment for autoimmune diseases? Israel Med Assoc J 2010; 12: 136-9.

17. Schwalfenberg GK. A review of the critical role of vitamin $D$ in the functioning of the immune system and the clinical implications of vitamin D deficiency. Mol Nutrition Food Res 2011; 55: 96-108.

18. Schleithoff SS, Zittermann A, Tenderich G, Berthold HK, Stehle P, Koerfer R. Vitamin D supplementation improves cytokine profiles in patients with congestive heart failure: a double-blind, randomized, placebo controlled trial. Am J Clin Nutr 2006; 83: 754-9.

19. Watson KE, Abrolat ML, Malone LL, et al. Active serum vitamin $D$ levels are inversely correlated with coronary calcification. Circulation 1997; 96: 1755-60.

20. Verhave G, Siegert CE. Role of vitamin D in cardiovascular disease. Neth J Med 2010; 68: 113-8.
21. Li X, Speer MY, Yang H, Bergen J, Giachelli CM. Vitamin D receptor activators induce an anticalcific paracrine program in macrophages: requirement of osteopontin. Arterioscler Thromb Vasc Biol 2010; 30: 321-6.

22. Oh J, Weng S, Felton SK, et al. 1,25(OH)2 vitamin D inhibits foam cell formation and suppresses macrophage cholesterol uptake in patients with type 2 diabetes mellitus. Circulation 2009; 120: 687-98.

23. Timms PM, Mannan N, Hitman GA, et al. Circulating MMP9, vitamin D and variation in the TIMP-1 response with VDR genotype: mechanisms for inflammatory damage in chronic disorders. QJM 2002; 95: 787-96.

24. Fic P, Zakrocka I, Kurzepa J, Stepulak A. [Matrix metalloproteinases and atherosclerosis]. Postepy Hig Med Dosw 2011; 65: 16-27.

25. Osborne JE, Hutchinson PE. Vitamin D and systemic cancer: is this relevant to malignant melanoma? $\mathrm{Br} J$ Dermatol 2002; 147: 197-213.

26. Ohsawa M, Koyama T, Yamamoto K, Hirosawa S, Kamei S, Kamiyama R. 1alpha, 25-dihydroxyvitamin D(3) and its potent synthetic analogs downregulate tissue factor and upregulate thrombomodulin expression in monocytic cells, counteracting the effects of tumor necrosis factor and oxidized LDL. Circulation 2000; 102: 2867-72.

27. Stach K, Kalsch Al, Nguyen XD, et al. 1alpha, 25-dihydroxyvitamin $\mathrm{d} 3$ attenuates platelet activation and the expression of vcam-1 and mt1-mmp in human endothelial cells. Cardiology 2011; 118: 107-15.

28. Al-Badr W, Martin KJ. Vitamin D and kidney disease. CJASN 2008; 3: 1555-60.

29. Vacek JL, Vanga SR, Good M, et al. Vitamin D deficiency and supplementation and relation to cardiovascular health. Am J Cardiol 2012; 109: 359-63.

30. Lee JH, Gadi R, Spertus JA, et al. Prevalence of vitamin D deficiency in patients with acute myocardial infarction. Am J Cardiol 2011; 107: 1636-8.

31. Kmieć P, Żmijewski M, Waszak P, Sworczak K, Lizakowska-Kmieć M. Vitamin D deficiency during winter months among an adult, predominantly urban, population in Northern Poland. Endokrynol Pol 2014; 65: 105-13.

32. Verdoia M, Schaffer A, Sartori C, et al. Vitamin D deficiency is independently associated with the extent of coronary artery disease. Eur J Clin Invest 2014; 44: 634-42.

33. Robinson-Cohen C, Hoofnagle AN, Ix JH, et al. Racial differences in the association of serum 25 -hydroxyvitamin $D$ concentration with coronary heart disease events. JAMA 2013; 310: 179-88.

34. Goleniewska BM, Kacprzak M, Zielinska M. Vitamin D level and extent of coronary stenotic lesions in patients with first acute myocardial infarction. Cardiol J 2014; 21: 18-23.

35. Verdoia M, Schaffer A, Barbieri L, et al. Impact of gender difference on vitamin $D$ status and its relationship with the extent of coronary artery disease. Nutr Metab Cardiovasc Dis 2015; 5: 464-70.

36. Jungert $A$, Neuhäuser-Berthold M. Sex-specific determinants of serum 25-hydroxyvitamin $D$ concentrations in an elderly German cohort: a cross-sectional. Nutr Metab (Lond) 2015; 12: 2.

37. Baigent C, Keech A, Kearney PM, et al. Cholesterol Treatment Trialists' (CTT) collaborators: efficacy and safety of cholesterol-lowering treatment: prospective meta-analysis of data from 900056 participants in 14 randomised trials of statins. Lancet 2005; 366: 1267-78.

38. Cannon CP, Braunwald E, McCabe $\mathrm{CH}$, et al. Intensive versus moderate lipid lowering with statins after acute 
coronary syndromes. N Engl J Med 2004; 350: 1495504.

39. García-Bailo B, Da Costa LA, Arora P, Karmali M, El-Sohemy $A$, Badawi A. Plasma vitamin D and biomarkers of cardiometabolic disease risk in adult Canadians, 2007 2009. Prev Chronic Dis 2013; 10: E91.

40. Gagnon C, Lu ZX, Magliano DJ, et al. Low serum 25-hydroxyvitamin $D$ is associated with increased risk of the development of the metabolic syndrome at five years: results from a national, population-based prospective study (The Australian Diabetes, Obesity and Lifestyle Study: AusDiab). J Clin Endocrinol Metab 2012; 97: 1953-61.

41. Gupta AK, Sexton RC, Rudney H. Effect of vitamin D3 derivatives on cholesterol synthesis and HMG-CoA reductase activity in cultured cells. J Lipid Res 1989; 30: 379-86.

42. Pérez-Castrillón JL, Vega G, Abad L, et al. The effects of atorvastatin on vitamin $D$ levels in patients with acute ischemic heart disease. Am J Cardiol 2007; 99: 903-5.

43. Wilczek H, Sobra J, Justová V, et al. latropathogenic effect of MEVACOR on vitamin D metabolism. Cas Lek Cesk 1989; 128: 1254-6.

44. Wilczek H, Sobra J, Ceska R, et al. Monitoring plasma levels of vitamin $D$ metabolites in simvastatin therapy in patients with familial hypercholesterolemia. Cas Lek Cesk 1994; 133: 727-9.

45. Pérez-Castrillón JL, Abad Manteca L, Vega G, et al. Vitamin D levels and lipid response to atorvastatin. Int J Endocrinol 2010; 2010: 320721. 